\title{
Expression of $\beta_{1}$-integrins and $\mathrm{N}$-cadherin in bladder cancer and melanoma cell lines ${ }^{\star \star \star}$
}

\author{
Piotr Laidler ${ }^{1}$, Dorota Gil ${ }^{1}$, Anna Pituch-Noworolska ${ }^{2}$, Dorota Ciołczyk ${ }^{1}$, Dorota \\ Książek ${ }^{1}$, Małgorzata Przybyło ${ }^{3}$ and Anna Lityńska ${ }^{3}$ \\ ${ }^{1}$ Institute of Medical Biochemistry, Collegium Medicum, Jagiellonian University, Kraków, \\ ${ }^{2}$ Department of Clinical Immunology, Polish-American Children's Hospital, Collegium Medicum, \\ Jagiellonian University, Kraków, ${ }^{3}$ Institute of Zoology, Department of Animal Physiology, \\ Jagiellonian University, Kraków, Poland
}

Received: 29 May, 2000; revised: 20 October, 2000; accepted: 14 November, 2000

Key words: cadherins, integrins, cell lines, cancer, cytofluorimetry

\begin{abstract}
Changes in the expression of integrins and cadherins might contribute to the progression, invasion and metastasis of transitional cell cancer of the bladder and of melanomas.

The expression of $\alpha_{5}(\boldsymbol{P}<0.001), \alpha_{2}$ and $\beta_{1}(\boldsymbol{P}<0.05-\boldsymbol{P}<0.001)$ integrin subunits in melanoma cells from noncutaneous metastatic sites (WM9, A375) were significantly increased as compared to cutaneous primary tumor (WM35) and metastatic (WM239) cell lines. These differences might be ascribed to the invasive character of melanoma cells and their metastasis to the noncutaneous locations.

The significantly heterogeneous expression of $\beta_{1}$ integrin subunit in two malignant bladder cancer cell lines (T24 and Hu456) and nonsignificant differences in the expression of $\alpha_{2}, \alpha_{3}$, and $\alpha_{5}$ subunits between malignant and non-malignant human bladder cell lines do not allow an unanimous conclusion on the role of these intergrin subunits in the progression of transitional cancer of bladder.

The adhesion molecule, expressed in all studied melanoma and bladder cell lines, that reacted with anti-Pan cadherin monoclonal antibodies was identified as N-cadherin except in the HCV29 non-malignant ureter cell line. However, neither this nor any other bladder or melanoma cell line expressed E-cadherin.
\end{abstract}

\footnotetext{
${ }^{\star}$ A preliminary report of the results was presented at $26^{\text {th }}$ FEBS Meeting, Nice, 1999, France.

This work was supported by the State Committee for Scientific Research (KBN, Poland) grant No. 6 P04A 02713 and in part 501/PkL/3/L (Collegium Medicum, Jagiellonian University)

${ }^{{ }}$To whom the correspondence should be addressed: Piotr Laidler, Institute of Medical Biochemistry, Collegium Medicum, Jagiellonian University, M. Kopernika 7, 31-034 Kraków; tel/fax: (48 12) 422 3272; e-mail: mblaidle@cyf-kr.edu.pl
}

Abbreviations: BSA, bovine serum albumin; FITC, fluoroscein conjugated; HRP, horseradish peroxidase; $\mathrm{mAbs}$, monoclonal antibodies; $\mathrm{NaCl} / \mathrm{P}_{\mathrm{i}}$, phosphate-buffered saline; $\mathrm{NaCl} /$ Tris, Tris-buffered saline. 
The obtained results imply that the replacement of E-cadherin by $\mathrm{N}$-cadherin accompanied by a simultaneous increase in expression of $\alpha_{2}, \alpha_{3}$ and $\alpha_{5}$ integrin subunits clearly indicates an increase of invasiveness of melanoma and, to a lesser extent, of transitional cell cancer of bladder. High expression of $\mathrm{N}$-cadherin and $\alpha_{5}$ integrin subunit seems to be associated with the most invasive melanoma phenotype.

Integrins are a family of cellular adhesion molecules involved in a number of the cellto-extracellular matrix proteins and the cell-to-cell interactions. These heterodimeric integral plasma membrane glycoproteins consist of sixteen $\alpha$ and eight $\beta$ type subunits that assemble into twenty two various cell surface receptors each exhibiting a different profile of ligand binding (Humphries \& Newham, 1998). Integrins are considered the molecules participating in outside-in and inside-out signaling due to the interactions of their cytoplasmic portions with cellular proteins and cytoskeleton (Longhurst \& Jennings, 1998). Therefore integrins are supposed to be involved in cell growth and differentiation, proliferation and migration, tissue organization, recruiting of lymphocytes and inflammation, cancer invasion and metastasis (Judware \& Culp, 1997; Sanders et al., 1998; Longhurst \& Jennings, 1998; Keely et al., 1998).

A significant number of studies focus on searching for a pattern of integrin expression characterizing invasive or metastatic cancer cells. Fujita et al. (1992) showed that members of the integrin $\beta_{1}$ subfamily played an important role in tissue attachment, migration, invasion and metastasis of human cancers. Treatment of carcinoma cells with antibodies against $\beta_{1}$ integrin subunit led to the inhibition of adhesion of carcinoma cells to laminin, fibronectin, collagens and various tissues as well as the inhibition of human bladder and gastric carcinoma invasiveness of the cells.

As concerns $\beta_{1}$ integrin, the $\alpha_{2} \beta_{1}, \alpha_{3} \beta_{1}$ and $\alpha_{5} \beta_{1}$ integrins were found by many authors to contribute to cancer cell invasion and metastasis. Increased expression of $\alpha_{3} \beta_{1}$ and $\alpha_{5} \beta_{1}$ integrins showed a correlation with invasive and metastatic potential of mammary carci- noma, glioma, transitional bladder cancer and melanoma cells (Tawil et al., 1996; Fukushima et al., 1998; Saito et al., 1996; Natali et al., 1995; Melchiori et al., 1995; Mortarini et al., 1993). On the other hand, progressive loss or decrease of $\alpha_{2} \beta_{1}$ integrin expression was observed in poorly differentiated mammary epithelial cells and an invasive phenotype of uroepithelial cells (Zutter et al., 1998; Liebert et al., 1994).

Cadherins, the calcium-dependent transmembrane glycoproteins mediating cellto-cell adhesion via homotypic interactions, are considered to be of utmost importance in organizing solid tissues. They are involved in early embryonic development and contribute to the maintenance of tissue integrity in differentiated epithelia and endothelia (Takeichi, 1991). Cadherins, like integrins, serve also as signaling receptors that affect cell proliferation (Caveda et al., 1996), differentiation (Larue et al., 1996) and migration (Monier- Gavelle \& Duband, 1995).

Huttenlocher et al. (1998) showed recently that contact inhibition of migration and motile activity of primary myoblasts are regulated by synergic action of integrin and cadherin receptors. Similarly, Wu et al. (1998) pointed to active participation of integrins in the assembly of extracellular matrix and the possible effect of integrins on the expression of E-cadherin. The results of both studies suggested close connections between these two families of cellular adhesion molecules.

Investigations on a large number of renal pelvis, ureter, bladder transitional cell cancers, breast, lung and pancreas carcinomas as well as papilloma cells and melanomas indicated that the selective loss of expression of E-cadherin could generate de-differentiation and invasiveness of human cancer cells 
(Birchmeier, 1995; Wakatsuki et al., 1996; Hsu et al., 1996; Matsuyoshi et al., 1997; Imao et al., 1999).

Only recently Giroldi et al. (1999) and Mialhe et al. (2000) found a predominant expression of N-cadherin over E-cadherin in bladder cancer cells. Similarly, Hazan et al. (1997) showed high expression of N-cadherin in the most invasive carcinoma cells from human breast. The expression of $\mathrm{N}$-cadherin was inversely correlated with E-cadherin expression, which suggested the functional role of $\mathrm{N}$-cadherin in facilitating the invasion and metastasis as well as in the cohesion of breast tumor cells.

The involvement of both integrins and cadherins in the regulation of diverse cellular processes and, in particular in the progression, invasion and metastasis of transitional cell cancer of bladder and melanomas prompted us to search for their expression pattern associated with an invasive phenotype of cancer cells.

\section{MATERIALS AND METHODS}

Cell lines and culture conditions. The cell lines of non-malignant transitional epithelial cell of ureter, HCV29, and transitional cell cancer of urine bladder, Hu456 (Vilien et al., 1983), T24 (HTB-4, ATCC, Bubenick et al., 1973) and v-raf transfected HCV29 line, BC3726, were used. These lines were obtained from the Cell Line Collection of the Institute of Immunology and Experimental Therapy, Polish Academy of Sciences (Wrocław, Poland).

Melanoma cell lines were obtained from the Department of Cancer Immunology, University School of Medical Sciences at Great Poland Cancer Center (Poznań, Poland). The WM35 line was from the primary tumor while WM9, WM239 (all established by Meenhard Herlyn, The Wistar Institute, Philadelphia, U.S.A.) and A375 (ATCC-CRL-1619, Giard et al., 1973) were from metastatic sites.
The cell lines were cultured in the RPMI medium 1640 (Sigma, Poznań, Poland) containing $10 \%$ fetal bovine serum (GibcoBRL ${ }^{\mathrm{TM}}$, or Boehringer) and antibiotics (penicillin, 100 $\mathrm{U} / \mathrm{ml}$; streptomycin, $100 \mu \mathrm{g} / \mathrm{ml}$; Polfa, Tarchomin, Poland). Cells were incubated at $37^{\circ} \mathrm{C}$ in a humidified atmosphere of $5 \% \mathrm{CO}_{2}$ in air.

Monoclonal and polyclonal antibodies. The following monoclonal antibodies (mAbs) were used: against $\alpha_{2} \beta_{1}$ and $\alpha_{3} \beta_{1}$ integrin specific to $\alpha_{2}$ (clone P1E6) and $\alpha_{3}$ (clone P1B5) subunits (DAKO); against $\alpha_{5} \beta_{1}$ integrin specific to $\alpha_{5}$ (clone $\mathrm{CDw} 49 \mathrm{e}$ ) and anti- $\beta_{1}$ subfamily (clone CD29/GPIIa) integrin subunits (Genosys Biotechnologies) as well as anti-human E-cadherin - clones HECD-1 and SHE78-7 (Zymed Laboratories), anti-VE-cadherin (Boehringer) and anti-Pan-cadherins (Sigma). Polyclonal rabbit antiserum against human N-cadherin was from R\&D Systems. The mouse $\mathrm{IgG}_{1}$ (DAKO), purified mouse myeloma $\operatorname{IgG}_{2 \mathrm{a}}$ and purified mouse myeloma $\mathrm{IgG}_{1}$ (Zymed Laboratories) were used as isotypic controls in parallel with a monoclonal antibody. FITC-conjugated rabbit anti-mouse immunoglobulins (F(ab2) fragment) (DAKO) and EnVision ${ }^{\mathrm{TM}} / \mathrm{HRP}$, anti-mouse (DAKO), or HRP-conjugated goat anti-rabbit immunoglobulins (Sigma) were used as second antibodies.

The integrins expression assay. Confluent cells were harvested from permanent culture with $0.05 \%$ trypsin/0.02\% EDTA standard solution (Sigma) and washed twice with phosphate-buffered saline $\left(\mathrm{NaCl} / \mathrm{P}_{\mathrm{j}}\right)$. The single-cell suspension $\left(1-2 \times 10^{6}\right.$ cells $\left./ \mathrm{ml}\right)$ was incubated in the presence of anti $\alpha_{2} \beta_{1}, \alpha_{3} \beta_{1}$, $\alpha_{5}$, or $\beta_{1}$ integrin mAbs (working dilutions in $\mathrm{NaCl} / \mathrm{P}_{\mathrm{i}}: 1: 3$ for anti- $\alpha_{2} \beta_{1}, 1: 10$ for anti- $\alpha_{3} \beta_{1}$ and 1:50 for anti- $\alpha_{5}$ and anti- $\beta_{1}$ integrin subunits) or isotypic control for $40-45 \mathrm{~min}$ at $4^{\circ} \mathrm{C}$. After incubation the cells were washed with $\mathrm{NaCl} / \mathrm{P}_{\mathrm{i}}$ and incubated with an excess of FITC-conjugated anti-mouse antibody (working dilution 1:50) for another 40-45 min at $4^{\circ} \mathrm{C}$. Afterwards the $\mathrm{NaCl} / \mathrm{P}_{\mathrm{i}}$ washed cells 
were suspended in $\mathrm{NaCl} / \mathrm{P}_{\mathrm{i}}(0.4 \mathrm{ml})$ and analyzed in the flow cytometer (FACScan, Becton Dickinson). The expression of $\alpha_{2}, \alpha_{3}, \alpha_{5}$, and $\beta_{1}$ integrin subunits was assayed after collection of 10000 events from each sample. The analysis of a gated cell population was based on the comparison of fluorescence intensity of the control and test samples.

The cadherins expression assay. The cells from permanent culture were detached with 0.02 M EDTA without trypsin ( $\mathrm{Hsu}$ et al., 1996), washed (once in $\mathrm{NaCl} / \mathrm{P}_{\mathrm{i}}$, twice in Tris-buffered saline, $\mathrm{NaCl} /$ Tris) and incubated with a first antibody (anti E-cadherin, 1:20 or anti VE-cadherin, 1:10 working dilutions in $\mathrm{NaCl} / \mathrm{Tris}$ ) for $1 \mathrm{~h}$ at $4^{\circ} \mathrm{C}$. Afterwards the cells were washed in $\mathrm{NaCl} /$ Tris and incubated with a second antibody (FITC-conjugated rabbit anti-mouse antibody - working dilution 1:50 in $\mathrm{NaCl} /$ Tris), then washed again, suspended in $0.4 \mathrm{ml}$ of $\mathrm{NaCl} /$ Tris and analysed in the flow cytometer. The staining with isotypic control was run in parallel.

To determine the cytoplasmic expression of cadherins the analysis was also performed on fixed cells. The suspension of cells in $\mathrm{NaCl} /$ Tris (50 $\mu \mathrm{l}$, about $10^{5}$ cells) was gently mixed with $200 \mu \mathrm{l}$ of Cytofix-Cytoperm (Pharmingen) and left for $20 \mathrm{~min}$ at $4^{\circ} \mathrm{C}$. Afterwards the cells were pelleted, washed in Perm/Wash ${ }^{\text {TM }}$ solution (Pharmingen) and stained with anti-Pan cadherin $\mathrm{mAb}$ (clone CH-19, working dilution 1:10) for 40-45 min at $4^{\circ} \mathrm{C}$ and FITC-conjugated rabbit anti-mouse immunoglobulins as the second antibody. The cytoplasmic expression of cadherin was assayed by flow cytometry.

Immunoprecipitation. Cells were harvested from culture dishes with a rubber policeman and washed with $\mathrm{NaCl} / \mathrm{P}_{\mathrm{i}}(3 \times)$, homogenized on ice three times by sonification, $5 \mathrm{~s}$ each (Bandelin Electronic) in $50 \mathrm{mM}$ Tris/HCl ( $\mathrm{pH}$ 7.5) containing 1 mM EDTA and proteinases inhibitor cocktail (P 2714, Sigma). The homogenate was left with $1 \%$ Triton X-100 and $0.3 \%$ protamine sulfate on ice (1 h) and centrifuged at $16000 \times \mathbf{g}\left(1 \mathrm{~h} \mathrm{at} 4^{\circ} \mathrm{C}\right)$.
Protein concentration was determined in supernatants according to Pederson (1977). The cell homogenate (100 $\mu \mathrm{g}$ of total protein) was incubated with anti-Pan cadherin antibody ( $3 \mu \mathrm{l}$ ) overnight at $4^{\circ} \mathrm{C}$ on an orbital rotator. Afterwards the sample was mixed with 15 $\mu \mathrm{l}$ of the homogeneous protein A cell suspension (Sigma) and incubated for $2 \mathrm{~h}$ at $4^{\circ} \mathrm{C}$ on an orbital rotator. The immunoprecipitate was washed six times with $\mathrm{NaCl} /$ Tris/Tween and boiled for $10 \mathrm{~min}$ in Laemmli sample buffer containing $\beta$-mercaptoethanol. The supernatant was then subjected to electrophoresis on $10 \%$ SDS/polyacrylamide gel (Laemmli, 1970).

Western blot analysis. The samples of extract of each cell line (100 $\mu \mathrm{g}$ of total protein) were run on SDS/PAGE using 10\% separation gel followed by electrophoretic transfer onto nitrocellulose. The blots were incubated overnight in $50 \mathrm{mM} \mathrm{NaCl} /$ Tris containing $2 \%$ bovine serum albumin (BSA) and $0.1 \%$ Tween 20 as blocking agents. Afterwards, the membrane was sequentially incubated with the first antibody (anti-Pan cadherin or anti-Ecadherin - working dilution $1: 500$ or $1: 200$, respectively) or anti-N-cadherin polyclonal rabbit antiserum (working dilution 1:200 in $\mathrm{NaCl} /$ Tris/Tween with 1\% BSA) for $20 \mathrm{~h}$ at $4^{\circ} \mathrm{C}$ followed by washing with $\mathrm{NaCl} /$ Tris/ Tween $(3 \times)$ and incubation with a second antibody EnVision ${ }^{\mathrm{TM}} / \mathrm{HRP}$, Anti-Mouse diluted 1:50 or HRP-conjugated goat anti-rabbit immunoglobulins (working dilution 1:500 in $\mathrm{NaCl} /$ Tris/Tween containing 1\% BSA). E-Cadherin and N-cadherin were detected using 3-amino-9-ethylcarbazole solutions (DAKO EnVision ${ }^{\mathrm{TM}}$ ) and 4-chloro-1-napthol (Sigma) in methanol-Tris/ $\mathrm{HCl}, \mathrm{pH} 7.5$, as substrates for horseradish peroxidase (HPR), respectively.

All remaining reagents were of analytical grade.

Statistical analysis. The results were compared by one-way ANOVA analysis of variance and the Tukey-Kramer multiple comparison test. 


\section{RESULTS}

\section{The expression of integrins in cell lines}

Flow cytometry studies carried out on four human urinary bladder and ureter cell lines showed that $\alpha_{2}, \alpha_{3}, \alpha_{5}$ and $\beta_{1}$ integrin subunits were expressed in all the cell lines in $54.6 \%$ to $91.61 \%$ (Fig. 1). The expression of $\alpha_{2}$, sion in the two malignant cell lines (Hu456 and T24) was highly significant $(P<0.001)$.

The line BC3726, a v-raf transfected non-malignant epithelial ureter line HCV29, showed a significantly lower expression of $\alpha_{2}, \alpha_{3}$ and $\alpha_{5}$ subunits $(P<0.01-P<0.001)$ as compared to malignant bladder cell lines (Hu456, T24). The difference in expression of $\alpha_{3}$ and $\alpha_{5}$ integrin subunits between HCV29 and
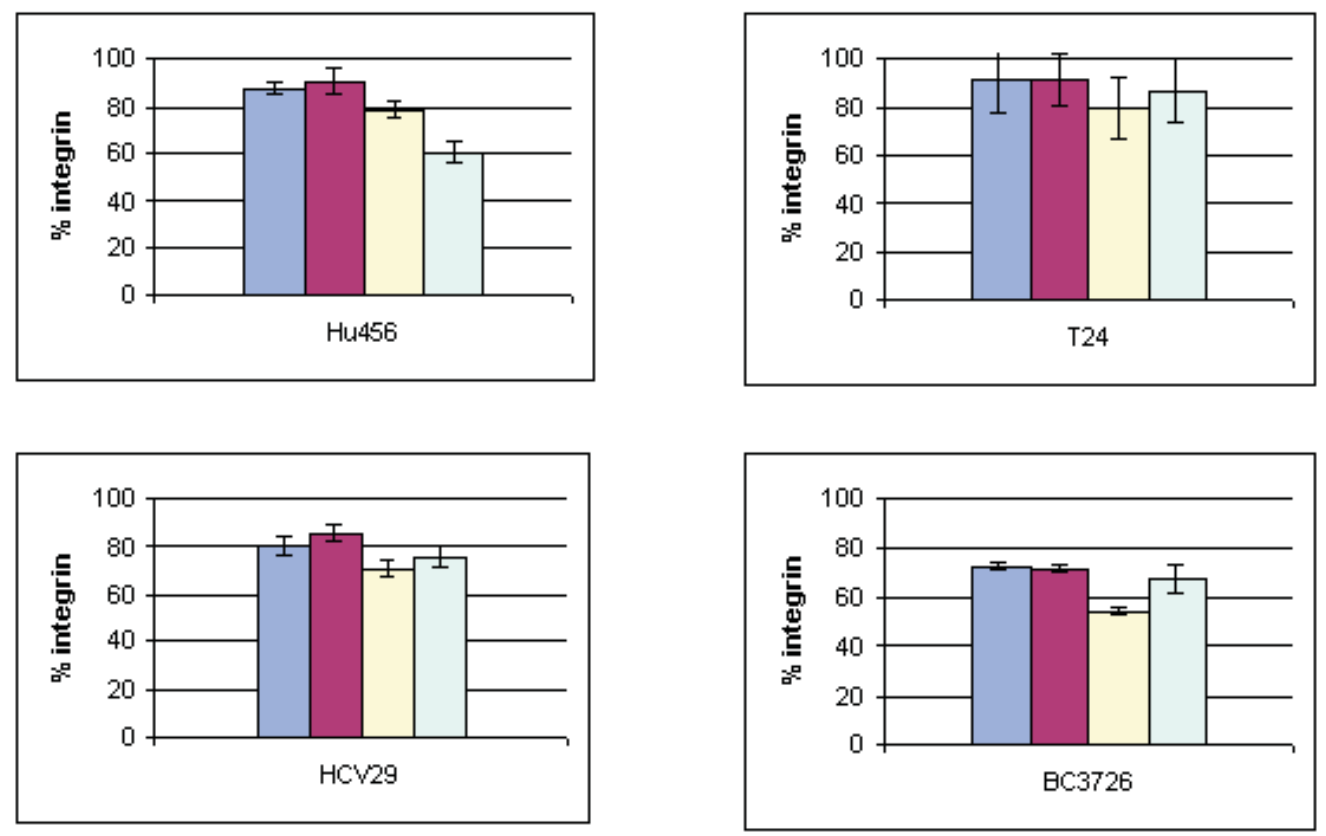

$\square \alpha_{2}$ subunit

$\alpha_{3}$ subunit

$\square \alpha_{5}$ subunit

$\square \beta_{1}$ subunit

Figure 1. The cell surface expression of integrin subunits in human bladder and ureter cell lines determined by flow cytometry as described under Materials and Methods.

Hu456, T24, transitional cell cancer of bladder; HCV, non-malignant transitional epithelial cells of ureter; BC3726, v-raf transfected HCV29 line. Bars for each cell line represent values, from left to right, for subunits $\alpha_{2}, \alpha_{3}, \alpha_{5}$, and $\beta_{1}$.

$\alpha_{3}$ and $\alpha_{5}$ in the two lines of transitional cell cancer of bladder - Hu456 and T24 - was higher than in their non-malignant counterpart HCV29 cell line but these differences were insignificant. The expression of $\beta_{1}$ subunit varied from $60.6 \%$ ( $\mathrm{Hu} 456$ ) to $86.8 \%$ (T24). The comparison of the non-malignant transitional cell from the ureter (HCV29) with a malignant cell of bladder cancer (Hu456) showed a significantly $(P<0.05)$ lower expression of the $\beta_{1}$ integrin subunit in Hu 456 cells while its expression was insignificantly higher in T2 4 cells. The difference between $\beta_{1}$ expres-
BC3726 was also significant $(P<0.01)$. However, the differences in expression of $\alpha_{3}$ and $\beta_{1}$ integrin subunit between HCV29 and BC3726 were insignificant.

Flow cytometry of $\alpha_{2}, \alpha_{3}, \alpha_{5}$ and $\beta_{1}$ integrin subunits in three cell lines of metastatic origin (WM239, WM9, A375) and one from the radial phase of a primary tumor (WM35) showed significantly lower $(P<0.05$ or $P<$ 0.001 ) expression of $\alpha_{2}$ subunit in the cell line from cutaneous primary (WM35) and cutaneous metastatic (WM239) tumor than in the other metastatic lesions cell lines (WM9, 
A375) (Fig. 2). Surprisingly, the difference between $\alpha_{2}$ expression in WM239 cell line and other noncutaneous metastatic cell lines (WM9, A375) was highly significant $(P<$ $0.001)$. The expression of $\alpha_{3}$ subunit was simi- cutaneous metastatic cell lines WM9 and A375 $(P<0.001)$.

The expression of $\beta_{1}$ was lower in primary and cutaneous metastatic tumor cell lines (WM35 and WM239, respectively) as com-
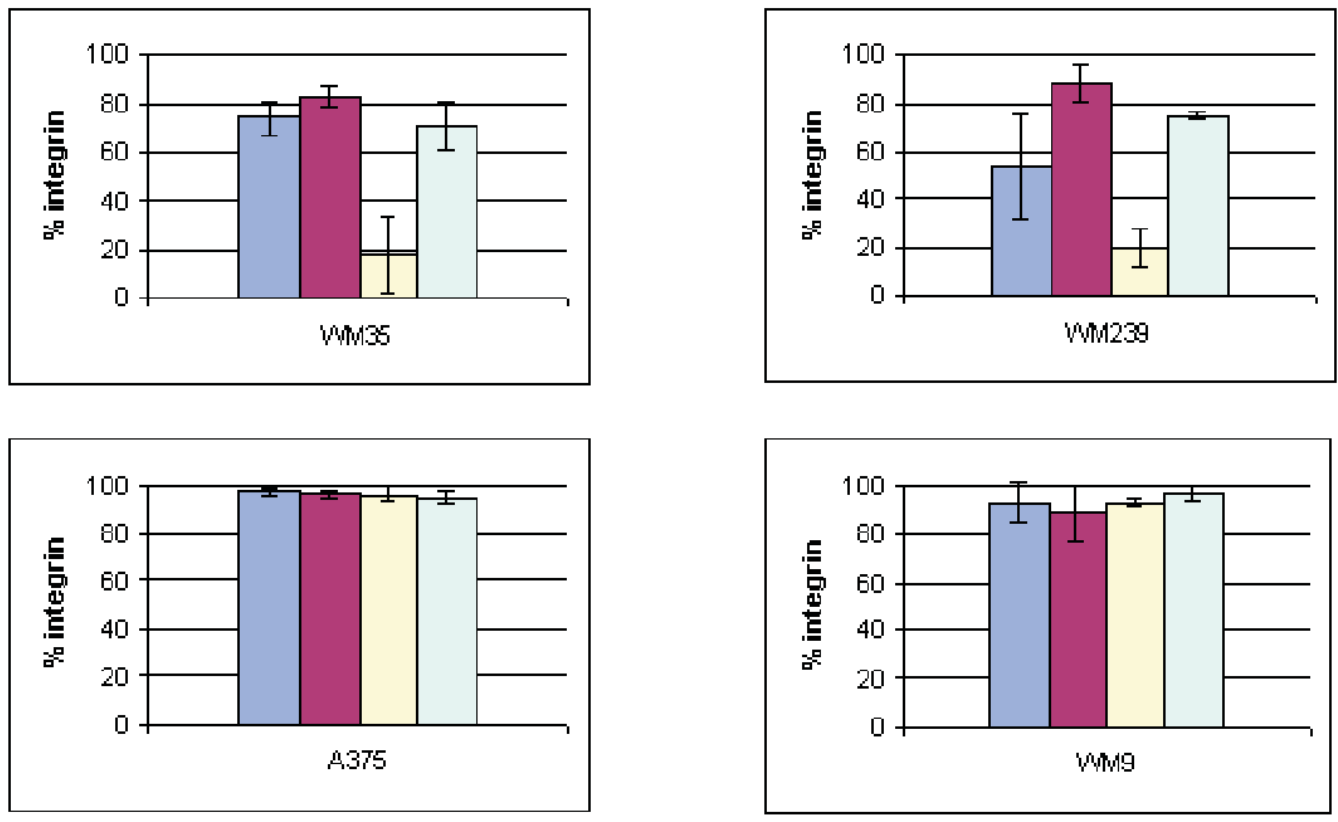

$\square \alpha_{2}$ subunit

$$
\text { - } \alpha_{3} \text { subunit } \square \alpha_{5} \text { subunit }
$$

$\square \beta_{1}$ subunit

Figure 2. The cell surface expression of integrin subunits in human melanoma cell lines determined by flow cytometry as described under Materials and Methods.

WM35, cutaneous primary tumor; WM239, cutaneous metastatic lesion; A375, metastatic lesion from solid tumour; WM9, lymphnode metastatic lesion. Bars for each cell line represent values, from left to right, for subunits $\alpha_{2}, \alpha_{3}, \alpha_{5}$, and $\beta_{1}$

lar, i.e. lower in WM35 and higher in the remaining lines including WM239. The differences were significant $(P<0.001)$ only between the expression of $\alpha_{3}$ subunit in WM35 and A375 lines. The expression of $\alpha_{3}$ subunit was similar in the two metastatic cell lines both of noncutaneous (WM9) and cutaneous (WM239) origin - but this expression was not as high as in the A375 line that represented high metastatic potential for the development of an amelanotic like melanoma tumors in nude mice (Giard et al., 1973).

The most interesting was a low expression of $\alpha_{5}$ integrin subunit in the line obtained from cutaneous primary tumor (WM35) and from cutaneous metastasis (WM239) which was significantly different from that in the non- pared to the expression in noncutaneous metastatic cells lines (WM9, A375). The observed differences were statistically significant $(P<$ 0.05 and $P<0.01$ ) for both cutaneous cell lines.

\section{The expression and identification of cadherins}

The analysis of cell extracts of bladder epithelial and melanoma lines using the standard Western blot procedure showed the presence of cadherin reacting with anti-Pan cadherin $\mathrm{mAb}$ against the $\mathrm{C}$-terminal peptide. The expression was quite high and ranged between 60 and $85 \%$ (over $75 \%$ for most of the cell lines) as was shown in the fixed cells using the 
same anti-Pan cadherin antibody (not shown). The cellular localization of cadherin to cell membranes was demonstrated by flow cytometry in the cells fixed on cytospin slides under a fluorescence microscope (Fig. 3).

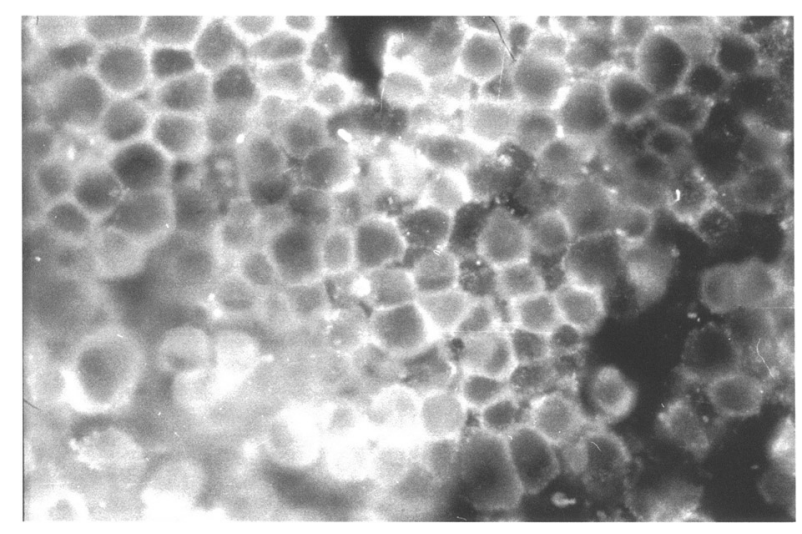

Figure 3. Intracellular localization of anti Pancadherin $\mathrm{mAb}$ reactive molecule studied on fixed cells (HCV29) on cytospin slides as described under Materials and Methods.

Parallel flow cytometric analysis of fixed HCV29 cell line showed high $(83.6 \%)$ expression of anti Pan-cadherin reactive $\mathrm{mAb}$ molecule (not shown).

The identification of cadherin performed with a few commercially available E-cadherin specific monoclonal antibodies (clones HECD-1 and SHE78-7 - Zymed Lab. or CH-19 - Boehringer) indicated the lack of E-cadherin in the studied bladder epithelial and melanoma cell lines. Similarly, using the same antibodies as for flow cytometry, we were unable to detect E-cadherin in the cell extracts.

The use of N-cadherin specific polyclonal antibodies against a part of its cytoplasmic portion and Western blotting unequivocally proved that $\mathrm{N}$-cadherin was the one previously found in the cell extracts using anti Pan-cadherin mAb (Fig. 4A). N-Cadherin was subsequently detected in all melanomas as well as in the transitional bladder cancer cell lines. It was also present in v-raf transfected cells, BC3726, but was missing or present in very minute amounts in its non-malignant counterpart, the HCV29 ureter epithelial cell line (Fig. 4B).

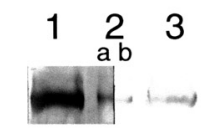

A

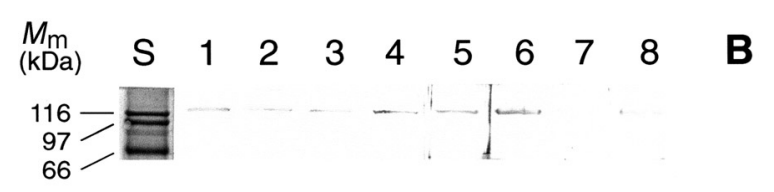

Figure 4. Western blot analysis of cadherins in cell extracts or immunoprecipitates of human bladder and melanoma cell lines.

A. Identification of cadherin type using cell extract and immunoprecipitate of A375 cell line as described under Materials and Methods. Lane 1, cell extract analyzed with anti-Pan cadherin $\mathrm{mAb}$; lane 2, anti Pan-cadherin reacting molecule immunoprecipitated from cell extract analyzed with: a, anti Pan-cadherin $\mathrm{mAb}$; b, anti N-cadherin polyclonal antiserum; lane 3, cell extract analyzed with anti $\mathrm{N}$-cadherin polyclonal antiserum. B. Cell extracts of human melanoma (1-4) and bladder (5-8) cell lines analyzed with anti N-cadherin polyclonal antiserum. 1, WM239; 2, WM35; 3, WM9; 4, A375; 5, T24; 6, Hu456; 7, HCV29; 8, BC3726; S, molecular mass standards (Sigma).

\section{DISCUSSION}

Many tumors exhibited downregulation or loss of expression of some integrins critical for stable adhesion while the expression of other which were involved in the migration of tumour cells through tissues, was retained or increased (Sanders et al., 1998). Our results clearly showed heterogenous cell surface expression of $\alpha_{2}, \alpha_{3}, \alpha_{5}$ and $\beta_{1}$ integrin subunits in human bladder cell lines. We have found higher expression of $\alpha$ type subunits in malignant bladder cells (Hu456 and T24) than in non-malignant epithelial urothelium cells (HCV29). The observed increase of expression of $\alpha_{5}$ integrin chain in the malignant transitional cells of bladder epithelia (Hu456, T24) compared to their non-malignant counterparts (HCV29) is consistent with the results of Saito et al. (1996) who reported that the increased expression of $\alpha_{5}$ integrin chain may 
be involved in the progression to a more malignant phenotype of bladder cancer.

One of the transitional cell cancer lines used in this study - T24, presenting the highest expression of $\beta_{1}$ integrin subunit out of all other lines, was earlier shown to be strongly dependent on the ability of $\beta_{1}$ integrin subunit to adhere to extracellular matrix proteins and some acetone-fixed tissues (Fujita et al., 1992). These results suggested the importance of the initial attachment of carcinoma cells to tissues by $\beta_{1}$ subunit as a first step in a process of invasion and metastasis. However, the second transitional cell cancer line (Hu456) showed the lowest expression of $\beta_{1}$ integrin subunit among all studied bladder cell lines. The significantly heterogeneous expression of this integrin subunit in two malignant bladder cancer cell lines (T24 and $\mathrm{Hu} 456)$ and nonsignificant difference in the expression of $\alpha_{2}, \alpha_{3}$ and $\alpha_{5}$ subunits between malignant and non-malignant cell lines do not allow an unequivocal conclusion on the role of these integrin subunits in the progression of transitional bladder cancer.

Interestingly, the expression of all four studied integrin chains in BC3726 cells (v-raf transfected human non-malignant epithelial urothelium cell line HCV29) was lower than in HCV29 cells. Shin et al. (1999) showed recently that the expression of $\alpha_{3} \beta_{1}$ integrin was significantly reduced in the endothelial cell line ECV304 stably transfected with H-Ras when compared to the parental ECV cells. A kinase effector of H-Ras, raf- 1 has been shown to block integrin activation in CHO-K1 cells (Hughes et al., 1997). These observations may suggest that v-raf transfection is a process leading to a decreased expression of $\alpha$ integrin subunits. Moreover, it creates a valuable model for studying their role in invasive and metastatic abilities of cancer cells.

The expression of $\alpha_{2}, \alpha_{3}, \alpha_{5}$ and $\beta_{1}$ integrin subunits was higher in melanoma cell lines from noncutaneous metastatic cell lines (WM9, A375), both from solid tumor and lymphnodes, than from cutaneous primary
(WM35) or cutaneous metastatic cell line (WM239). The highest expression of $\alpha_{3}$ integrin chain in highly metastatic A375 cell line is consistent with the results of Natali et al. (1995) and Melchiori et al. (1995) who suggested that the increase of $\alpha_{3} \beta_{1}$ integrin expression is critical during melanoma cell progression to a malignant, invasive phenotype.

A significant increase of $\alpha_{2}$ integrin chain expression in metastatic melanomas of noncutaneous origin (WM9, A375) as compared to cutaneous primary (WM35) and metastatic (WM239) lines points to a possible role of $\alpha_{2} \beta_{1}$ integrin in the invasion and development of distant metastases of melanoma.

The most striking observation concerns the expression of $\alpha_{5}$ subunit since, in cutaneous melanoma, both primary (WM35) and metastatic (WM239) cell lines, it was as low as 20\% while in metastatic cell lines of noncutaneous origin (WM9, A375) it reached over 90\%. Similar conclusions were drawn on the metastatic potential of several different human melanoma cell lines injected intravenously or subcutaneously to nude mice. Regardless of their origin only cell lines M7, M13, MV3 and WM 98-1 which expressed $\alpha_{5}$ subunit in the range of $63-100 \%$, developed metastasis (Schadendorf et al., 1996). Moreover, the recent results of immunohistochemical analysis of integrin expression in the sections of melanoma tumor tissues (Marshall et al., 1998) indicated the expression of $\alpha_{5}$ subunit in a significant percentage of nodal (5/9) but not of skin (1/8) metastases. These results might suggest a relation between expression of this integrin subunit and the ability of melanoma cells to colonize preferentially lymph nodes. On the other hand, the results obtained by Huttenlocher et al. (1998) on $\alpha_{5}$ integrin in the myoblasts in wounds imply a specific and important role of $\alpha_{5}$ in the migration of melanoma cells during metastasis into distinct noncutaneous and not necessarily nodal locations.

As recently shown the $\beta_{1}$ integrin subunit is expressed in melanoma cell lines regardless of their origin - uveal or cutaneous (Marshall et 
al., 1998). The expression of this integrin was also high in all studied melanomas. A significant increase reported here of $\beta_{1}$ integrin subunit in metastatic cells lines of noncutaneous origin (WM9, A375) in comparison with cutaneous primary and metastatic cell lines (WM35 and WM239, respectively) might suggest participation of $\beta_{1}$ subunit in cancer invasion and metastasis.

The present studies showed a consistent high cell surface expression of anti-Pan cadherin reactive adhesion molecules in all bladder and melanoma cell lines. Neither cell surface expression of E-cadherin nor its presence in the cell extract of any studied cell line was observed.

E-Cadherins are viewed as major cellto-cell homotypic adhesion molecules commonly expressed in various epithelial cells. It is rather generally accepted that the loss or decrease of surface expression of E-cadherin may lead to invasive and metastatic phenotypes of epithelial cancers (Birchmeier, 1995; Wakatsuki et al., 1996; Schofield et al., 1997; Humphries \& Newham, 1998; Christofori \& Semb, 1999; Imao et al., 1999). The expression of E-cadherin was restricted to melanocytes, and most of melanomas had lost E-cadherin (Danen et al., 1996; Furukawa et al., 1997). Wakatsuki et al. (1996) and Imao et al. (1999) did not find E-cadherin expression in human bladder transitional cell cancer line T24 but detected E-cadherin in two noninvasive superficial human bladder cancer cell lines RT4 and KK47.

Recent comparative studies on the expression of cadherins in normal and cancer cell lines of human prostate, breast, bladder and melanomas as well as lymphomas strongly pointed to an inverse correlation between the expression of N- and E-cadherin (Tran et al., 1999; Hazan et al., 1997; Giroldi et al., 1999; Hsu et al., 1996; Kawamura-Kodama et al., 1998). In all these tumors the loss of E-cadherin and the simultaneous increase of N-cadherin seemed to lead the N-cadherin expressing cells toward a progressively invasive phe- notype. The progression from an epithelial to a mesenchymal phenotype could explain their higher ability to interact with the surrounding stromal fibroblasts thus facilitating invasion and metastasis (Tran et al., 1999; Hazan et al., 1997; Kawamura-Kodama et al., 1998).

Our results confirmed that the replacement of E-cadherin by $\mathrm{N}$-cadherin is associated with the progression of non-malignant cells to invasive melanomas (WM35, WM239, WM9, A375) and malignant transitional bladder cancers (T24, Hu456). However, at least in the case of melanoma, the expression of N-cadherin by itself does not seem to predict the course of invasion. Based on our studies in vitro it seems that not N-cadherin itself but rather the increased expression of $\alpha_{5}$ integrin subunit influences the $\mathrm{N}$-cadherin bearing melanoma cells to overstep the primary site and develop distant metastatic lesions.

As shown in the non-malignant HCV29 bladder line, low expression of all three $\alpha$ subunits need not be associated with evident expression of E-cadherin. The lack of E-cadherin expression in the non-malignant epithelial urothelium cell line HCV29 was associated with the absence or only trace amounts of $\mathrm{N}$-cadherin. This indicates that a lack of E-cadherin may be a phenomenon characteristic for in vitro culture of bladder cell lines.

Cadherin staining with anti-Pan cadherin monoclonal antibody in lymphomas not expressing E-cadherin may be considered as an example of the exchange of cadherins expression in the course of tumor progression (Ashton-Key et al., 1995). The identification of six novel different cadherins in human melanoma cells showed that their expression is far more complicated in melanomas than in melanocytes (Matsuyoshi et al., 1997). Moreover, various cells could change the pattern of cadherin expression in different surrounding environment. Changes in the cell-cell interactions during migration of tumor cells are accompanied by evident changes in the profile of cadherins (Voura et al., 1998) and strongly support the view of "cross-talks" between mol- 
ecules representing cadherin and integrin families (Huttenlocher et al., 1998).

The replacement of E-cadherin by $\mathrm{N}$-cadherin associated with the expression of $\alpha_{2}, \alpha_{3}$ and $\alpha_{5}$ integrin subunits await further search on the mechanisms responsible for the integrated reprofiling of the expression of these adhesion molecules leading to progressive changes in cell phenotype.

The authors wish to thank Prof. Andrzej Mackiewicz from the Department of Cancer Immunology, University School of Medical Sciences at Great Poland Cancer Center (Poznań, Poland) for valuable discussion concerning melanoma cell lines and Mrs Maria Łabędź for excellent technical assistance.

\section{R E F E R E N C ES}

Ashton-Key, M., Cowley, G.P. \& Smith, M.E.F. (1995) Cadherins in reactive lymph nodes and lymphomas: High expression in anaplastic large cell lymphomas. Histopatology 28, $55-59$.

Birchmeier, W. (1995) E-Cadherin as a tumor invasion suppressor gene. BioEssays 17, 97-99.

Bubenick, J., Baresova, M., Viklicky, V., Jakoubkova, J., Sainerova, H. \& Donner, J. (1973) Established cell line of urinary bladder carcinoma (T24) containing tumor specific antigen. Int. J. Cancer 11, 765-773.

Caveda, L.I., Martin-Padura, P., Navarro, F., Brevario, M., Corado, D., Gulino, M. \& Lampugnani Dejana, E. (1996) Inhibition of cultured cell growth by vascular endothelial cadherin (cadherin-5/VE-cadherin). J. Clin. Invest. 98, 886-893.

Christofori, G. \& Semb, H. (1999) The role of the cell-adhesion molecule E-cadherin as a tumour-suppressor gene. Trends Biochem. Sci. 24, 73-76.

Danen, E.H., de Vries, T.J., Morandini, R., Ghanem, G.G., Ruiter, D.J. \& van Muijen, G.N. (1996) E-Cadherin expression in human melanoma. Melanoma Res. 6, 127-131.
Fujita, S., Suzuki, H., Kinoshita, M. \& Hirohashi, S. (1992) Inhibition of cell attachment, invasion and metastasis of human carcinoma cells by anti-integrin $\beta_{1}$ subunit antibody. Jpn. J. Cancer Res. 83, 1317-1326.

Fukushima, Y., Ohnishi, T., Arita, N., Hayakawa, T. \& Sekiguchi, K. (1998) Integrin $\alpha_{5} \beta_{1}$-mediated interaction with laminin-5 stimulates adhesion, migration and invasion of malignant glioma cells. Int. J. Cancer 76, 63-72.

Furukawa, F., Fujii, K., Horiguchi, Y., Matsuyoshi, N., Fujita, M., Toda, K., Imamura, S., Wakita, H., Shirahama, S. \& Tagikawa, M. (1997) Roles of E- and P-cadherin in the human skin. Microscopy Res. Tech. 38, 343-352.

Giard, D.J., Aaronson, S.A., Todaro, G.J., Arnstein, P., Kersey, J. H., Dosik, H. \& Parks, W.P. (1973) In vitro cultivation of human tumors: Establishment of cell lines derived from a series of solid tumors. J. Natl. Cancer Inst. 51, 1417-1423.

Giroldi, L.A., Bringuier, P.P., Shimazui, T., Jansen, K. \& Schalken, J.A. (1999) Changes in cadherin-catenin complexes in the progression of human bladder carcinoma. Int. J. Cancer 82, 70- 76 .

Hazan, R.B., Kang, L., Whooley, B.P. \& Borgen, P.I. (1997) N-Cadherin promotes adhesion between invasive breast cancer cells and the stroma. Cell Adhesion \& Commun. 4, 399-411.

Hughes, P.E., Renshaw, M.W., Pfaff, M., Forsyth, J., Keivens, V.M., Schwartz, M.A. \& Ginsberg, M.H. (1997) Supression of integrin activation: A novel function of a Ras/Raf-initiated MAP kinase pathway. Cell 88, 521-530.

Humphries, M.J. \& Newham, P. (1998) The structure of cell adhesion molecules. Cell Biol. 8, 78-83.

Huttenlocher, A., Lakonishok, M., Kinder, M., $\mathrm{Wu}$, S. \& Truong, T. (1998) Integrin and cadherin synergy regulates contact inhibition of migration and motile activity. J. Cell Biol. 141, 515-526.

Hsu, M.J., Wheelock, M.J., Jonson, K.R. \& Herlyn, M. (1996) Shifts in cadherin profiles between human normal melanocytes and melanomas. J. Invest. Dermatol. 1, 188-194. 
Imao, T., Koshida, K., Endo, Y., Uchibayashi, T., Sasaki, T. \& Namiki, M. (1999) Dominant role of E-cadherin in the progression of bladder cancer. J. Urol. 161, 692-698.

Judware, R. \& Culp, L.A. (1997) Extracellular matrix and matrix receptors: Alterations during tumor progression. Encyclopedia of Cancer 1, $660-679$.

Kawamura-Kodama, K., Tsutsui, J., Suzuki, S.T., Kanzaki, T. \& Ozawa, M. (1998) N-Cadherin expressed on malignant $\mathrm{T}$ cell lymphoma cells is functional, and promotes heterotypic adhesion between the lymphoma cells and mesenchymal cells expressing $\mathrm{N}$-cadherin. J. Invest. Dermatol. 112, 62-66.

Keely, P., Parise, L. \& Juliano, R. (1998) Integrins and GTPases in tumour cell growth, motility and invasion. Trends Cell Biol. 8, 101-106.

Laemmli, U.K. (1970) Cleavage of structural proteins during assembly of the head of bacteriophage T4. Nature 227, 680-685.

Larue, L.C., Antos, S., Butz, O., Huber, V., Delmas, M. \& Kemler, R. (1996) A role for cadherins in tissue formation. Development (Camb) 122, 3185-3194.

Liebert, M., Washington, R., Stein, J., Wedemeyer, G. \& Grossman, H.B. (1994) Expression of the VLA $\beta_{1}$ integrin family in bladder cancer. Am. J. Pathol. 144, 1016-1022.

Longhurst, C.M. \& Jennings, L.K. (1998) Integrinmediated signal transduction. Cell. Mol. Life Sci. 54, 514-526.

Marshall, J.F., Rutherford, D.C., Happerfield, L., Hanby, A., McCartney, A.C.E., NewtonBishop, J. \& Hart, I.R. (1998) Comparative analysis of integrins in vitro and in vivo in uveal and cutaneous melanomas. British $J$. Cancer 77, 522-529.

Matsuyoshi, N., Tanaka, T., Toda, K. \& Imamura, S. (1997) Identification of novel cadherins expressed in human melanoma cells. J. Invest. Dermatol. 108, 908-913.

Melchiori, A., Mortarini, R., Carlone, S., Marchisio, P.C., Anichini, A., Noonan, D.N. \& Albini, A. (1995) The $\alpha_{3} \beta_{1}$ integrin is involved in melanoma cell migration and invasion. Exp. Cell Res. 219, 233-242.
Mialhe, A., Levacher, G., Champelovier, P., Martel, V., Serres, M., Knudsen, K. \& Seigneurin, D. (2000) Expression of E-, P-, N-cadherins and catenins in human bladder carcinoma cell lines. J. Urol. 164, 826-835.

Monier-Gavelle, F. \& Duband, J.-L. (1995) Control of N-cadherin-mediated intercellular adhesion in migrating neural crest cells in vitro. J. Cell Sci. 108, 3839-3853.

Mortarini, R., Gismondi, A., Santoni, A., Parmiani, G. \& Anchini, A. (1993) Role of the $\alpha_{5} \beta_{1}$ integrin receptor in the proliferative response to quiescent human melanoma cells to fibronectin. Cancer Res. 52, 4499-4506.

Natali, P.G., Nicotra, M.R., Filippo, F.Di. \& Bigotti, A. (1995) Expression of fibronectin, fibronectin isoforms and integrin receptors in melanocytic lesions. British J. Cancer 71, 12431247.

Pederson, L. (1977) A simplification of the protein assay method of Lowry which is more generally applicable. Anal. Biochem. 83, 346-356.

Saito, T., Kimura, M., Kawasaki, T., Sato, S. \& Tomita, Y. (1996) Correlation between integrin $\alpha_{5}$ expression and the malignant phenotype of transitional cell carcinoma. British $J$. Cancer 73, 327-331.

Sanders, R., Mainiero, F. \& Giancotti, F. (1998) The role of integrins in tumorigenesis and metastasis. Cancer Invest. 16, 329-344.

Schadendorf, D., Fichtner, I., Makki, A., Alijagic, S., Kupper, M., Mrowietz, U. \& Henz, B.M. (1996) Metastatic potential of human melanoma cells in nude mice - characterisation of phenotype, cytokine secretion and tumour-associated antigens. British J. Cancer 74, $194-$ 199.

Schofield, K., D’Aquila, T. \& Rimm, D.L. (1997) The cell adhesion molecule, E-cadherin, distinguishes mesothelial cells from carcinoma cells in fluids. Cancer Cytopathol. 81, 293-298.

Shin, E.-Y., Lee, J.-Y., Park, M.-K., Jeong, G.-B., Kim, E.-G. \& Kim, S.-Y. (1999) H-Ras is a negative regulator of $\alpha_{3} \beta_{1}$ integrin expression in ECV304 endothelial cells. Biochem. Biophys. Res. Commun. 257, 95-99. 
Takeichi, M. (1991) Cadherin cell adhesion receptors as a morphogenetic regulator. Science 251, 1451-1455.

Tawil, N.J., Gowri, V., Dioneidi, M., Nip, J., Carbonetto, S. \& Brodt, P. (1996) Integrin $\alpha_{3} \beta_{1}$ can promote adhesion and spreading of metastatic breast carcinoma cells on the lymph node stroma. Int. J. Cancer. 66, 703-710.

Tran, N.L., Nagle, R.B., Cress, A.E. \& Heimark, R.L. (1999) N-Cadherin expression in human prostate carcinoma cell lines. An epithelialmesenchymal transformation mediating adhesion with stromal cells. Am. J. Pathol. 155, 787-798.

Vilien, M., Christensen, B., Wolf, H., Rassmussen, F., Hou-Jensen, C. \& Povlsen, C.O. (1983) Comparative studies of normal, 'spontaneously' transformed and malignant human urothelium cells in vitro. Eur. J. Cancer Clin. Oncol. 19, 775-789.
Voura, E.B., Sanding, M. \& Siu, C.H. (1998) Cell-cell interactions during transendothelial migration of tumor cells. Microscopy Res. Tech. 43, 265-275.

Wakatsuki, S., Watanabe, R., Saito, K., Saito, T., Katagiri, A., Sato, S. \& Tomita, Y. (1996) Loss of human E-cadherin (ECD) correlated with invasiveness of transitional cell cancer in the renal pelvis, ureter and urinary bladder. Cancer Lett. 103, 11-17.

Wu, Ch., Keightley, S., Leung-Hagestein, Ch., Radeval, G., Coppolino, M., Goicoechea, S., McDonald, A.J. \& Dedhar, S. (1998) Integrinlinked protein kinase regulates fibronectin matrix assembly, E-cadherin expression, and tumorigenicity. J. Biol. Chem. 273, 528-536.

Zutter, M.M., Sun, H. \& Santoro, S. (1998) Altered integrin expression and the malignant phenotype: The contribution of multiple integrated integrin receptors. J. Mammary Gland Biol. Neopl. 3, 191-199. 